International Journal of Physical Sciences and Engineering
Available online at http://sciencescholar.us/journal/index.php/ijpse
Vol. 3 No. 1, April 2019, pages: 10 21
e-ISSN : 2550-6943, p-ISSN : 2550-6951
https://doi.org/10.29332/ijpse.v3n1.239

\title{
The Geoportal as Strategy for Sustainable Development
}

Bravo Bazurto d
Article history: Received 27 July 2018, Accepted: 31 December 2018, Published: 8 January 2019

e-ISSN: 2550-6943, p-ISSN: 2550-6951 ๑ Copyright 2019. The Author. SS Journals Published by Universidad Técnica de Manabí. This is an open-access article under the CC BY-SA 4.0 license (https://creativecommons.org/licenses/by-sa/4.0/) All rights reserved.

a Teaching Researcher, Ph.D., Engineering in Electricity, FCMFQ, Universidad Tecnica de Manabi, Portoviejo, Ecuador

b Teaching Researcher, MsC, Industrial Engineering career, FCMFQ, Universidad Tecnica de Manabi, Portoviejo Ecuador

c Systems engineer, MsC, Information technology and communications management, Universidad Tecnica de Manabi, Portoviejo Ecuador

d Systems engineer, MsC, Information technology and communications management. Universidad Tecnica de Manabi, Portoviejo Ecuador 


\section{Contents}

Abstract

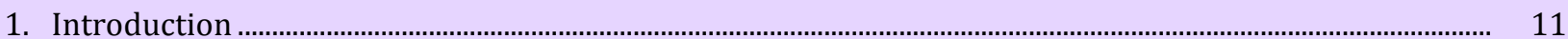

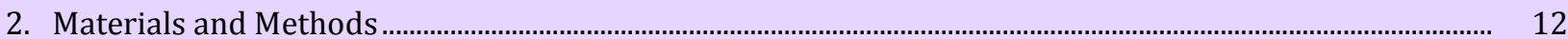

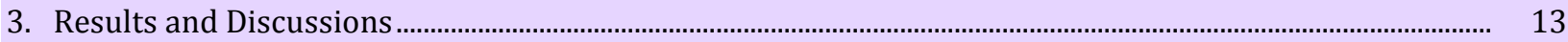

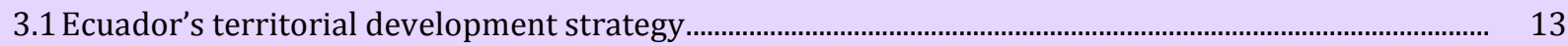

3.2 Relevance of geographic information systems (GIS) …....................................................................................

3.3 Importance of a GEOWEB for sustainable development................................................................................. 14

3.4 Proposal of the geographic information system for sustainable development (SIGDS) ............................15

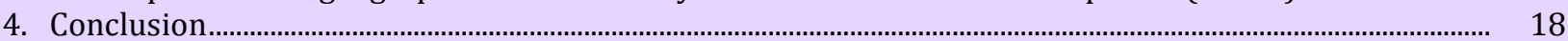

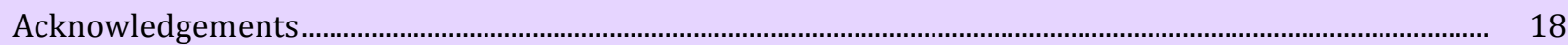

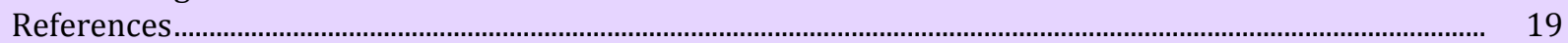

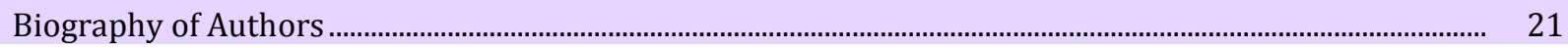

\section{Introduction}

The information society constitutes an effective means for the management of territorial resources, as well as a mechanism of transparency and control that society has for the development of policies focused on sustainable development (Omer, 2017; Pérez et al., 2018; Gamez et al., 2017). It can be analyzed that currently, $1 \%$ of the population have what $99 \%$ need, demonstrating the dramatic situation that society faces on a global scale (Stiglitz, 2012). That is why it is stated that in the XXI century the time has come to assume the responsibility of acting from politics, citizenship, and companies, especially in the local environment and from other perspectives or thoughts. It is clear that cooperation for development means helping to eliminate extreme poverty, but also inequalities in rights and freedoms, ensuring the quality of life and a future for all (Calvo et al., 2014).

The study of the processes of innovation in the new economic spaces characterized by the agglomeration of specialized productive activities and close collaboration and competition relations between agents of production, trade, and services, is an example of the relational turn that has taken place in the economic geography since the 1990s (Salon, 2003).

The studies carried out in recent years on the issue related to development show that, through the application of traditional models of technical scientific progress, which focus on developing solutions and with a centralized vision of planning, it is very difficult to reach the goals related to sustainability and much less the balanced and equitable development of society. There is a need to rethink the usual patterns of development, focusing the vision on the empowerment of local factors and the adequate use of indigenous resources.

But frequently, the image of the territory that social agents possess does not exactly match the geographical reality or the relationships established therein (Rodríguez \& Vázquez, 2018). The paradigm associated with the use of the endogenous resources of each territory can create innovative technological alternatives, while at the same time it constitutes an instrument for the application of policies focused on sustainable development (Vázquez, 2017). This change of paradigm will not be useful if a critical analysis of the economic reality is not made, that allows to create strategic planning articulated with the territorial ordering, that constitutes a fundamental element in the planning process for the sustainable development (Ubilla \& Villegas, 2017).

To face the challenge of social sustainability, tools are needed that are capable of transparent relevant information associated with the availability of endogenous resources from the local level and the different technological variants that allow their optimal use in order to meet the growing needs of society and society. where resource potentials can be located in a timely manner (Rodríguez \& Vázquez, 2018). It requires a high vision in the decision making from the physical to the functional, from the administrative to the economic and directed to sustainable development, taking into account the impacts of technologies on the environment (Arias et al., 2015).

The objective of the research is to propose a website based on the politics of the knowledge society, which aims to make available to stakeholders and especially social actors at the local level, relevant information linked to the availability of endogenous resources that can be used to promote sustainable development from

Gamez, M. R., Perez, A. V., Sera, A. S., \& Ronquillo, Z. M. (2017). Renewable energy sources and local development. International Journal of Social Sciences and Humanities, 1(2), 10-19. https://doi.org/10.29332/ijssh.v1n2.31 
the local level. The proposed application will allow access to interested parties, such as undergraduate, master's and doctoral students and project managers, regarding relevant data related to endogenous resources for sustainable development in Ecuador, from anywhere in the world, provided that you have a computer and access to the internet, for the management of sustainable local development projects.

\section{Materials and Methods}

In order to develop the work, the client-server architecture was used, which is a distributed application model in which the tasks are distributed among the providers of resources or services, called servers, and the claimants called clients. The Prado, Extjs, Geoext and OpenLayers technologies were also used as a PHP framework, with the aim of making possible the manipulation of each module of the application. The javascript library called ExtJS version 3.4.0, is used with the objective of improving the interaction with the user, as it offers the ability to provide components with advanced functionalities and easy implementation. They are easy to use and intuitive.

As a server, the Geoserver was used, which an open source server is written in Java, which allows users to share and edit geospatial data. The design of databases is obtained from the statistical reports that the client receives from the different levels of the territory and from a geographical information system (GIS) the databases that must be used by the users were pre-designed.

The design proposed web geo is the one currently used by computer systems called multilevel architecture or layered programming. In these architectures, each level is entrusted with a simple mission, which allows the design of scalable architectures (which can easily be extended in case the needs increase). The most used design is three levels (or three layers). Figure 1 shows the proposed design.

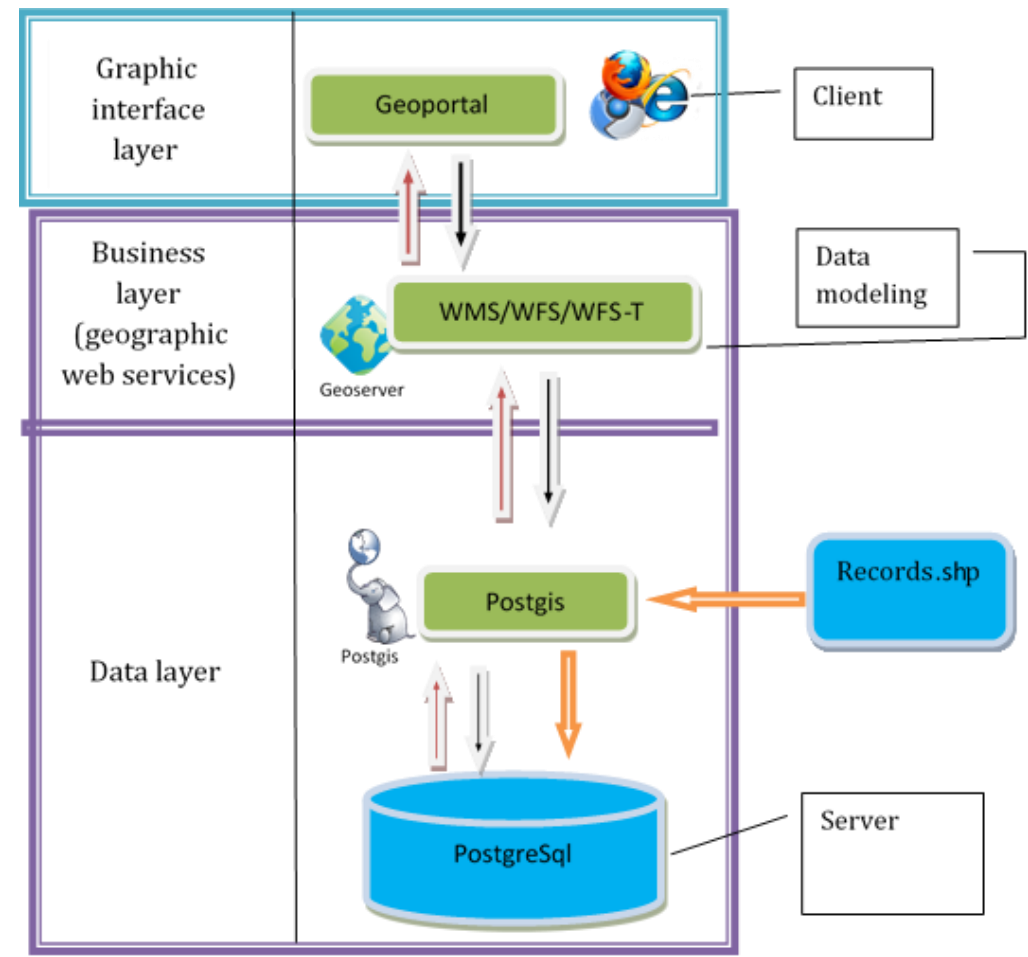

Figure 1. Computer design system

The graphics interface layer or presentation layer is what the user sees, it is also called the user layer, it has been developed in such a way that it presents the system to the user, communicates the information and captures it the information in a minimum of process (performs a previous filtering to check that there are no 
format errors). It has been made in a friendly way (understandable and easy to use). This layer communicates only with the business layer.

The business layer is where there side programs that are executed, it receives the user's requests and the responses are sent after the process. It is called a business layer (and even business logic) because this is where all the rules that must be met are established. This layer communicates with the presentation layer, to receive the requests and present the results and with the data layer, to request the manager to database store or retrieve data from it. Application programs are also considered here.

The data layer is where the data resides, is responsible for accessing them. It is formed by one or more database managers who perform all the storage of these, receive requests for storage or retrieval of information from the business layer. For the cartographic information, the one published on the regional scale web page 1: 250,000, version January 2013 was used. Layers of basic geographic information of the Institute of Military Geography (IGM) of free access. (UTF-8 coding) (IGM, 2013). For the management of the information of the potentials linked to incident solar radiation and wind speed, the information corresponding to the databases published on the NASA website was used (Whitlock, 2015).

\section{Results and Discussions}

\subsection{Ecuador's territorial development strategy}

Traditionally, the concept of development is the offspring of the western notion of progress that emerged in classical Greece and consolidated in Europe since the mid-eighteenth century, when the flashes of illustration began to shine. , under the assumption that the reason would allow discovering the general laws that organize and regulate the social order and thus be able to transform it for the benefit of the people (Valcárcel, 2006).

The industrial revolution meant a strong increase in the demand for raw materials and energy and it is from that moment that development is conceived through a linear possibilist thinking, with attachment to technical traditions (Claval, 2000), which has led too far the criterion of satisfaction of human needs and cravings, leaving aside the complex social relations that are established between society and the environment, attributing to science miraculous powers capable of solving any problem.

Until the end of the 19th century, science had not demonstrated the environmental effects and the accelerated exhaustion of natural resources that had already accumulated man's predatory and irresponsible activity, therefore, neither ethically nor scientifically there was any place for such concerns (Viamonte et al., 2007).

The extraordinary development of technique and science achieved by humanity in the twentieth century demonstrated the ambivalence of the creation of the human mind. The sublime and positive has seen the light next to the negative and despicable. A model of development that has led the human species to live in two worlds: one endowed with every possible comfort and another that faces every day a desperate struggle for survival and against hunger, illiteracy and disease; a first world that has achieved this condition based on the sustained depauperation of a third polluted world, desertified and impoverished in its natural resources (Viamonte et al., 2007).

The society of the 21st century recognizes that it is very difficult to achieve the articulation of social progress that is coherent and sustainable, through the practice of a policy anchored in the philosophy traced by the traditional models of the development of capitalism in the mid-eighteenth century. It is necessary to put into play a new type of development that does not make the same mistakes of past societies, a type of development that prioritizes community priorities based on their own resources, a development that empowers society of its own destiny.

The current strategy of territorial development of Ecuador, foresees the deconcentration of management and services, outlining the development of the different zones of the country, foreseeing financing of more than nine billion dollars between 2014 and 2017. The policy deployed has sought to strengthen the national structure of human settlements, in a polycentric, articulated and complementary manner, in line with what the National Plan for Good Living formulates. That is, that public services and development reach the different territories of the country (Larrea, 2013).

Gamez, M. R., Perez, A. V., Sera, A. S., \& Ronquillo, Z. M. (2017). Renewable energy sources and local development. International Journal of Social Sciences and Humanities, 1(2), 10-19. https://doi.org/10.29332/ijssh.vIn2.31 
The new model proposes to establish poles of development in different provinces and close gaps in inequality and poverty, for which state investment has focused on public services such as education, health, prevention, social inclusion, internal security, water, and sewerage. The social importance consists in the study and search of new models that assure the sustainability of life, understood the development as an integral phenomenon that also includes the economic concept, everything related to the life of the society, including the intangible cultural heritage.

Its geographic interest consists of achieving a model of progress coupled with the concepts of territorial development, where it is based on the use of endogenous resources in full harmony with the traditions and cultures of society. The economic importance of the project is based on its own nature, since it is about studying new models of local development, which guarantee a more efficient integral management, where the environmental footprint derived from social development can be minimized and the cost of living for the children reduced. Citizens (Larrea, 2013).

\subsection{Relevance of geographic information systems (GIS)}

At the international level, there are various information systems at different levels, global, regional and country, which are linked to the theme of sustainable development for different uses. Its fundamental objective is to provide information to be used depending on different applications. Google Earth is one of the most known and used information systems worldwide, which allows taking cartographic information to social agents, scholars and interested parties (Google, 2012); however, as a weakness, it could be pointed out that it does not offer energy information.

The countries of the European Union have drawn up a strategy for the integration of renewable energies in 100 Communities, based on the study of the available potential and the appropriate technology so that they can assess integrated energy systems for local supply. The communities have created local information systems adapted to the specific conditions of each place, the available resources and the type of supply, so that the information is reliable, of quality and that allows the continuity of sustainable energy development (EC, 1997).

An example of the development carried out by some countries is the project entitled "Geographic Information System for Renewable Energy (SIGER), which promotes the technical analysis of the introduction of renewable energy sources (FRE) in the Spanish electricity generation system (Pinedo, 2007).

The Latin American Energy Organization (OLADE) is developing an energy information platform for Latin America and the Caribbean, adaptable and reliable that helps in the effective management and control of planning in the field of energy in member countries. It allows for comparative analysis and projections of the sector with official and validated information, ideal for decision-making at the national, subregional and regional levels. The system makes available to the countries the Regional Energy Information System (SIE), a fundamental element for the integration of statistical, prospective, legal and documental information of the energy sector of the Region (OLADE, 2018).

The Law for the use of renewable energies and the Financing of the energy transition in Mexico (CDHCU, 2013), establishes that the energy secretariat should prepare and keep updated the National Inventory of Renewable Energies, where the Energy Secretariat instructed to the Electrical Research Institute (IIE) to carry out the work that will lead to the preparation of said inventory and the subsequent updates. In Venezuela, the geographic information system has been used to estimate the potential of solar energy (Posso et al., 2014).

\subsection{Importance of a GEOWEB for sustainable development}

The integration of geographic information systems in the web environment allows professionals dedicated to the development of geospatial information to publish directly metadata about their services, as well as maps, information and a complex variety of services that users can see, use, combine and enjoy to create applications, meaning more opportunities to share information and take advantage of other services in the interest of sustainable development.

GeoWeb based systems are no longer simply tools for visualization and creation of simple maps, but become the support for the integration of services based on GIS, which represent a source of real data, maps, 
results of complex models and applications, where users can create new bases for spatial analysis linked to the realization of projects focused on sustainability (Rodríguez, 2012).

There are some experiences based on web initiatives that are supported in geographic information systems, with the aim of promoting the adequate use of endogenous resources, among which we can point out the case of Cuba, where it was verified that the information of the FRE found dispersed in the different sectors and companies of the state, including universities and research centers, corroborating that there was no system that automatically integrated the information, so it worked on different versions of information systems, validated to level of municipality, generalized at province and regional level, managing to develop a version of the GIS for use in rural electrification through the use of renewable energies (Marquez et al., 2005).

In order to materialize the idea of grouping and making information transparent, we worked on the inventory of renewable energy resources and renewable potentials in Cuba, for which the project entitled Geographical Information System of Renewable Sources of Energy was articulated, achieving the development of a web application through an energy geoportal, which allowed international access to the database of renewable resources throughout the country and which offered relevant information support for the realization of research projects in universities and research centers in the country and in the Foreign. (Rodríguez et al., 2011).

\subsection{Proposal of the geographic information system for sustainable development (SIGDS)}

Manabí is the third province with respect to population size with $9.6 \%$ of the country's total population, in relation to the surface, it has $6.83 \%$ of the national territory, which represents the sixth place in size, with a population density of 75.8 inhabitants per square kilometer (Egas, 2013). The annual growth rate is 1.65\%. The average age of the population is 28.2 years. Illiteracy in people older than or equal to 15 years is $10.2 \%$ and digital illiteracy in people over ten years of age is 34.3\% (Aster-GDEM, 2014). 63\% of its population is in the urban area, this is 862961 inhabitants and 37\% in the rural area, that is, 506819 inhabitants. This relationship is mainly due to the fact that the most populated cantons such as Portoviejo and Manta have $94 \%$ and $95 \%$ of their population in the urban area respectively, these two cantons represent $55 \%$ of the total provincial urban population and when analyzing the Data related to socioeconomic development in these cities concentrates more than $60 \%$ of gross domestic product (GDP) (Egas, 2013).

The analysis of the potential of natural and human resources and the socio-economic situation of the Manabí territory makes it possible to define that there are conditions to assume a decentralized development model, based on the use of indigenous resources, profiled with environmental respect and achievement, of a sustainable development that allows the socioeconomic balance of the territories, with the aim of achieving greater social equity. But all this may be possible insofar as conditions can be created that propitiate the adequate use of the indigenous resources available to the territory and in this, the level of access to relevant information related to the availability of endogenous resources plays an important role and the technological possibilities of its use in the distributed scheme of local development.

Considering the international experiences supported on web pages based on georeferenced information, at the Technical University of Manabí, the SIGDS project was developed, which aims to provide relevant information related to the availability of endogenous resources in order to facilitate the sustainable development of the territory. For this, we work on the SIGDS project, which aims to create an open-access geoportal with information related to the availability of endogenous resources and the technologies that make it possible to use them, as well as other data that may be of interest for development sustainable of the localities.

The process seen in a general way begins when a geospatial request is made from the client side and sent to some of the services offered by the server, which is responsible for processing them and resolving the requested by making transactions to the database independence of the type of request that is and carries out pertinent actions so that the information returned by the database arrives with the appropriate format to the client. In the layer of business (Geographic web services) is the Geoserver tool that works on the server side and provides the geographic services Wms, Wfs, Wfs-T among others.

The GeoServer works as an open source server written in Java, which allows users to share and edit geospatial data. It has been designed from the start to operate under interoperability standards. It is capable of publishing services from the main data sources using open standards (www.zonageo.com.ar). Geoserver

Gamez, M. R., Perez, A. V., Sera, A. S., \& Ronquillo, Z. M. (2017). Renewable energy sources and local development. International Journal of Social Sciences and Humanities, 1(2), 10-19.

https://doi.org/10.29332/ijssh.v1n2.31 
version 2.1.2 has been used as a geospatial data server, that is, a map server and its data, which allows users to consult and edit data through the project.

Based on the design of the system and the knowledge of the availability of endogenous resources in the territory, it has been possible to carry out the inventories of these, but with the system already designed, the information that will allow updating the system can be introduced.

The inventories are related to the different alternatives for sustainable development such as renewable resources, main crops, soil availability for agricultural production, as well as the installation of shrimp farms, the situation of soil quality for buildings, etc. Figure 2 shows the input interface to the SIGDS.

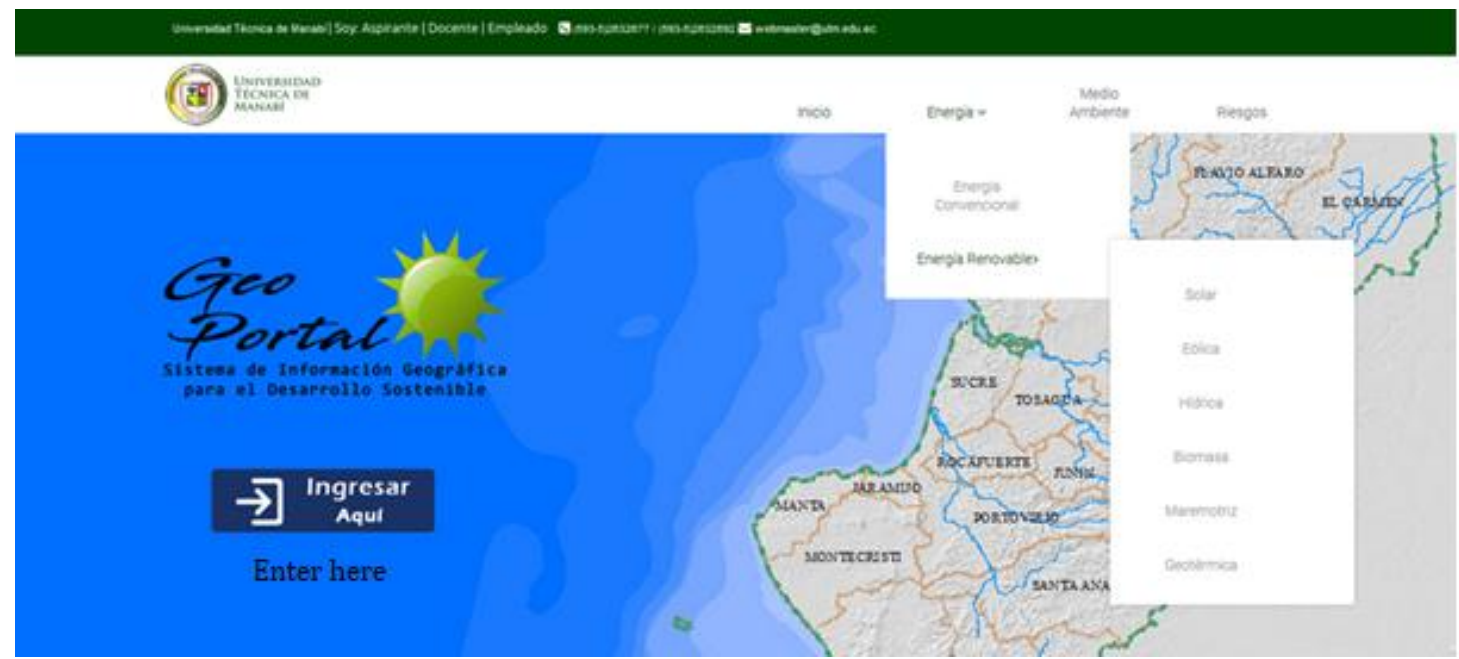

Figure 2. Input interface to the SIGDS

The system is capable of displaying an application of the specific types of each of the alternatives related to the availability of endogenous resources. The inventories are distributed throughout the territory of the province, allowing the knowledge of which sites or social and economic objectives, being able to analyze their location to maintain vitality in special situations or natural disasters.

Figure 3 shows the inventory related to the availability of solar potential in the territory of the province, being able to observe that throughout the territory there is a solar radiation that can be exploited for the generation of clean and cheap energy during the 365 days of the year without interruption, constituting a real alternative of sustainable development through the use of an endogenous resource. 


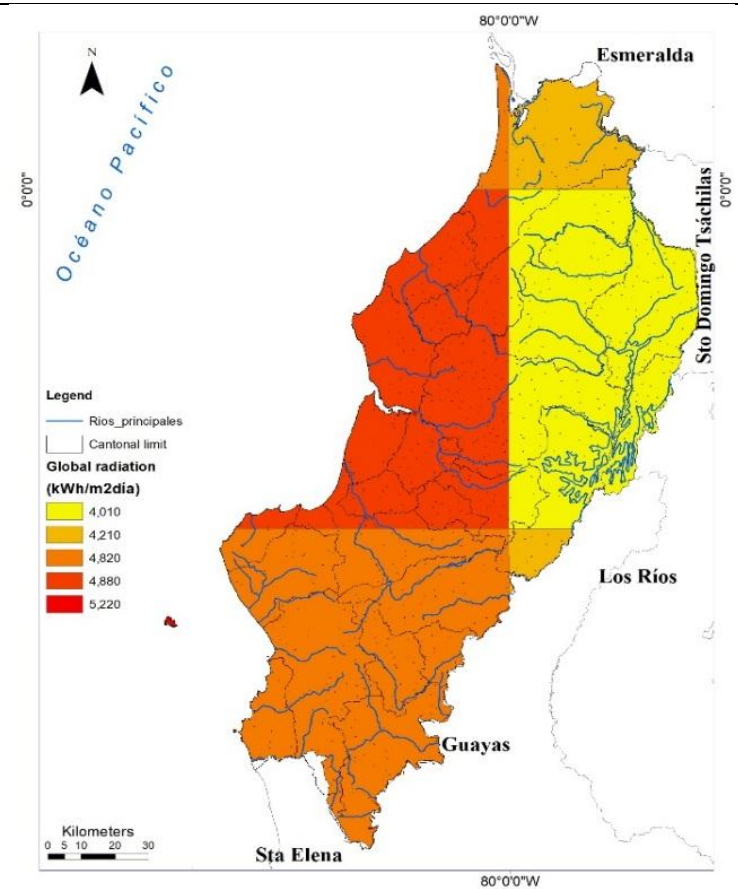

Figure 3. Inventory of solar radiation in the province of Manabí

The system offers the potential to provide timely information related to the inventory of endogenous resources. Just click on the site from which you need to obtain the data and the required information appears. Figure 4 shows an example of the data that is offered.

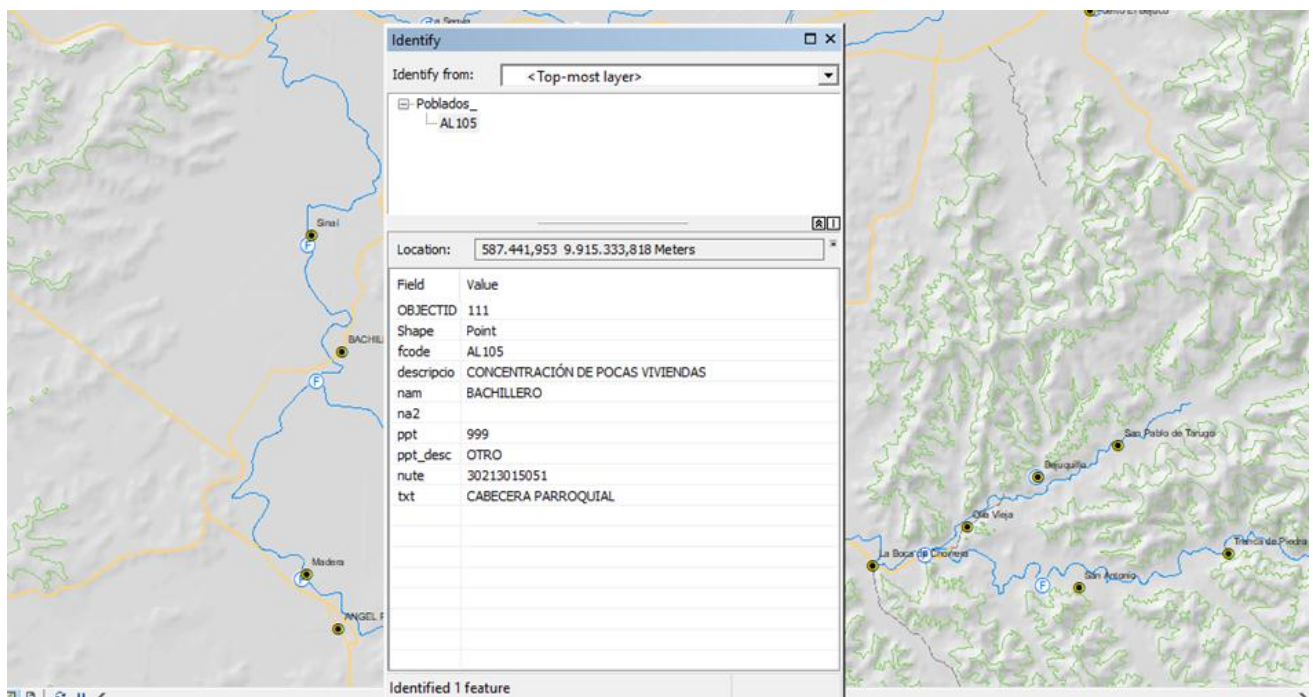

Figure 4. A sample of specific information offered by the system

This information is of necessity and decisive for the researchers who will develop local development projects, by offering data that will allow knowing in the future the number of houses and populations in each place studied; besides the autochthonous renewable potential being able to direct the development to the use and exploitation of those resources oriented to the sustainable development.

The data and information contained in the system can be widely used by professors, researchers, students, and staff interested in sustainable development alternatives, in order to articulate research projects focused

Gamez, M. R., Perez, A. V., Sera, A. S., \& Ronquillo, Z. M. (2017). Renewable energy sources and local development. International Journal of Social Sciences and Humanities, 1(2), 10-19. https://doi.org/10.29332/ijssh.v1n2.31 
on solving problems at the level of communities and localities. With the publication of the SIGDS geoportal on the web, local actors can achieve a more dynamic role and participation in the tasks linked to the sustainable development of society.

\section{Conclusion}

The proposed geoportal constitutes a friendly tool that is easily manipulated by users, based on the principles of the knowledge and information society, with proven potential to promote alternative solutions for sustainable development from the localities; It can also be used for the registration, control, and generalization of a diverse data field, linked to the inventory of endogenous resources of the localities, as well as to offer relevant information related to the technological use of these resources, which demonstrates the versatility of the system.

\section{Acknowledgments}

The authors are grateful to the director of the information and communications technology department Ing. Master, José Aristides Valencia Ruiz for their support in the creation of the technical infrastructure for the development of the research in its first stage. 
References

Arias, Gri, González, SR, Herrera, SA, \& Pérez, QM (2015). Exploitation of Ecuadorian Amazonian agrobiodiversity and human capital formation. Venezuelan Geographical Magazine. Institutional Repository of the University of Los Andes, Mérida - Venezuela.

Aster-Gdem. (2014). Aster gdem - aster gdem version 1. Accessed on October 31, 2017.

Bravo, G. U., \& Salgado, R. V. (2017). Objetivos de los planes de desarrollo comunal (PLADECO) y ordenamiento territorial regional: servicios ecosistémicos y desarrollo de nuevas centralidades para la Región Metropolitana de Santiago. Revista Geografica Venezolana, 58(1), 62-85.

Calvo, PR, Portet, TJ, \& Bou, PM (2014). Social equity as an essential element for local development. University of Valencia, Consulted on October 31, 2017.

Carrasco, J. S. (2003). Innovación y actores locales en los nuevos espacios económicos: un estado de la cuestión. Boletín de la Asociación de Geógrafos Españoles, (36).

Castillo, G. A. L., Álava, L. A. C., Fernández, M. C., \& Llanes, M. V. (2017). Roadmap for the introduction of smart grids in Ecuador. International Journal of Physical Sciences and Engineering, 1(2), 1-10. https://doi.org/10.21744/ijpse.v1i2.28

CDHCU. (2013). Law for the use of renewable energies and the financing of the energy transition. Chamber of Deputies of the Honorable Congress of the Union. General Secretary. Secretariat of Parliamentary Services, Latest Reforms DOF 07-06-2013.

Claval, P. (2011). Les voyages américains de Vidal de la Blache et de Demangeon: Évolution de leur vision de la géographie et du monde.Cahiers de géographie du Québec,55(155), 263-277. https://doi.org/10.7202/1007385ar

EC. (1997). European Commission. Energy for the future Renewable Sources OF Energy. White Paper for a Community Strategy and Action Plan.

Egas, THA (2013). Analysis of the economic impact in the province of Manabí, due to the construction of the Eloy Alfaro Pacific Refinery. Institute of High National Studies. Postgraduate University of the State. Thesis to apply for the Master's Degree in Senior Management.

Gamez, M. R., Perez, A. V., Sera, A. S., \& Ronquillo, Z. M. (2017). Renewable energy sources and local development. International Journal of Social Sciences and Humanities, 1(2), 10-19. https://doi.org/10.29332/ijssh.v1n2.31

Larrea, MAM (2013). Territorial development is a priority of the equator. National Secretary of Planning and Development, Consulted on May 17, 2017.

Marquez, S., Rodriguez, GM, Chery, E., Cisnero, I., \& Morell, M. (2005). Use of the geographic information system (sig) as a tool in decision-making in the rural electrification program. Scientific journal of renewable energies, ISBN: 959-250-2005, (ISSN: 1028 6004).

Omer, A. (2017). Sustainable development and environmentally friendly energy systems. International Journal of Physical Sciences and Engineering, 1(1), 1-39. https://doi.org/10.21744/ijpse.v1i1.2

Pérez, A. V., Gámez, M. R., Briones, V. F. V., Viteri, C. G. V., \& Molina, L. A. V. (2018). Sustainable development seen from environmental training in university linkage. International Journal of Life Sciences, 2(1), $12-20$. https://doi.org/10.29332/ijls.v2n1.75

Pinedo Pascua, I. (2007). Geographical Information Systems and the Integration of Renewable Energies in the Electrification of Rural Communities. Case Study: Electrification of the Cuban Municipality of Guama; Aplicacion de los Sistemas de Informacion Geografica a la Integracion de las Energias Renovables en la Produccion de Electricidad en las Comunidades Rurales. Caso de Estudio: Electrificacion del Municipio Cubano de Guama.

Posso, F., González, J., Guerra, F., \& Gómez, H. (2014). Estimación del potencial de energía solar en Venezuela utilizando sistemas de información geográfica. Revista Geográfica Venezolana, 55(1).

Rodríguez, GM, \& Vázquez, PA (2018). La energía fotovoltaica en la provincia de Manabí. Colección libros de texto. Universidad Técnica de Manabí. Ediciones UTM. Unidad de Cooperación Universitaria ISBN: 9789942-948-20-5.

Stiglitz, J. E. (2012). El precio de la desigualdad: el 1\% de población tiene lo que el 99\% necesita. Taurus.

Valcárcel, M. (2006). Génesis Y Evolución Del Concepto Y Enfoques Sobre El Desarrollo Documento de investigación. Departamento de Ciencias Sociales. Pontificia Universidad Católica del Perú. Recuperado de

Gamez, M. R., Perez, A. V., Sera, A. S., \& Ronquillo, Z. M. (2017). Renewable energy sources and local development. International Journal of Social Sciences and Humanities, 1(2), 10-19. https://doi.org/10.29332/ijssh.v1n2.31 
http://www. ucipfg. com/Repositorio/MGTS/MGTS15/MGTSV15-01/SEMANA1/71583949-Genesis-yEvolucion-Del-Concepto-de-Desarrllo. pdf.

Vázquez, PA (2017). Energy, local development and territorial planning. Lambert Academic Publishing (LAP), ISBN: 978-620-2-09497-9.

Viamonte, E., \& autores, Cd (2007). Derecho ambiental cubano. Editorial Felix Varela Segunda edición actualizada y aumentada. ISBN 978-959-07-0434-5.

Wave Of. (2018). We are united by energy. SIEE. Website of the Latin American Energy Organization (OLADE).

Whitlock, C. H., Brown, D. E., Chandler, W. S., DiPasquale, R. C., Meloche, N., Leng, G. J., ... \& Kratz, D. P. (2000). Release 3 NASA surface meteorology and solar energy data set for renewable energy industry use. Proceedings of Rise and Shine.

Whitmeyer, S. J. (Ed.). (2012). Google Earth and virtual visualizations in geoscience education and research (Vol. 492). Geological Society of America. 


\section{Biography of Authors}

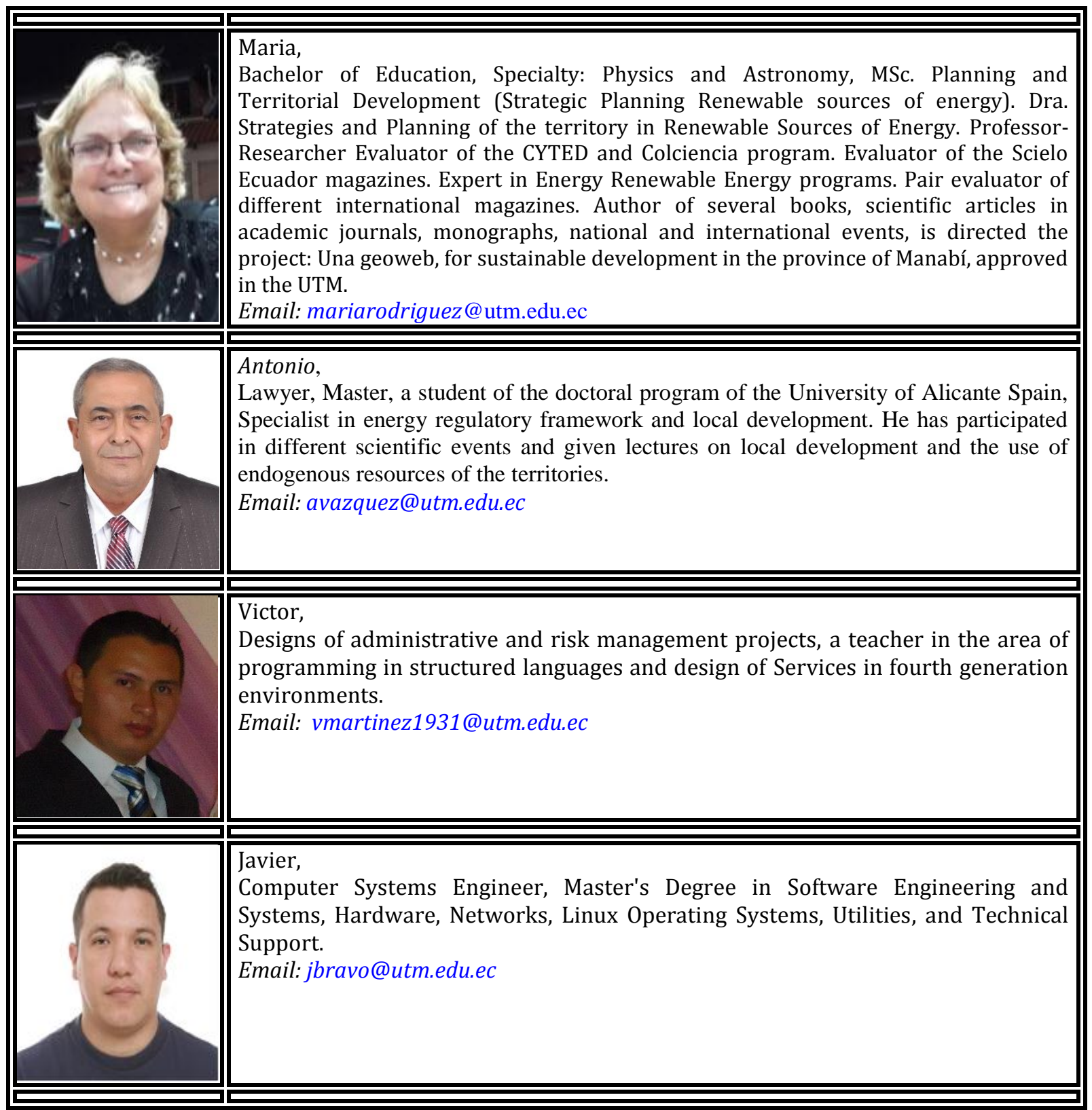

Gamez, M. R., Perez, A. V., Sera, A. S., \& Ronquillo, Z. M. (2017). Renewable energy sources and local development. International Journal of Social Sciences and Humanities, 1(2), 10-19. https://doi.org/10.29332/ijssh.v1n2.31 